\title{
Effect of Farm Investment Support on Multiple and Informal Borrowing of Farm Households: A Case Study on Rythubandhu Scheme in Telangana, India
}

\author{
Sravanthi Kolla* and P. Raghu Rami Reddy \\ Department of Agricultural Economics, Agricultural College, Palem, \\ Nagarkarnool District, India \\ *Corresponding author
}

\section{Keywords}

Farm investment support, Multiple borrowing, Informal borrowing and Quasi-poission model

\section{Article Info}

Accepted:

18 November 2020

Available Online:

10 December 2020

\section{A B S T R A C T}

Farm household's over indebtedness is an emerging issue in developing countries. Many studies concluded that multiple and informal borrowing are reasons for households over indebtedness. Governments have been taking many reactive and proactive policies to correct the situation. Farm investment support schemes are one such proactive policies popular across sub-Saharan Africa and emerging in India. In this context, this study was conducted to estimate the effect of farm investment support scheme on multiple and informal borrowing. One such scheme Rythubandhu implementing by Telangana state government in India is chosen for this study. Data collected from 72 farm households across the state. Quasipoission model was used to find out the various factors affecting multiple borrowing and Logit regression model was fitted to determine the factors effecting informal borrowing. Results indicated that investment support may not necessarily reduce the multiple or informal borrowing of a household but creating irrigation facilities to the operating land may significantly reduce household's overindebtedness.

\section{Introduction}

Debt is an important financial instrument for a household to induce private investment and for smooth consumption. However, household over indebtedness is emerging as a financial crisis globally and in rural areas of the developing economies especially. The problem will be cascaded by Economies entering COVID 19 pandemic with already stretched debt burden (World Bank, 2020).

\section{Over-indebtedness- Multiple and informal borrowing}

Recently many studies were conducted across different emerging economies to determine important drivers for over indebtedness of 
rural household (in Thailand and Vietnam (Chichaibelu and Waibel, 2018; Klühs et al., 2018) and in India (Puliyakot and Pradhan, 2018; Thorat, 2020). Multiple and informal borrowing are the major factors that drive a household to be over-indebted (Puliyakot and Pradhan, 2018). A field study by Pandy et al., 2019 established that multiple borrowing from institutions along with informal sources is the reason for pushing rural household into a debt trap situation.

Informal lenders play tactics to trap their borrowers in debt by hindering them to invest profitably by charging high interest rates (Bhattacharjee and Rajeev, 2013). On other hand improvement in institutional lending leads to "trickle down" effect where rich borrowers demand more which in turn decreases the bargaining power of poor borrowers in informal credit markets causing them to be trapped at low level of wealth (Liu et al., 2016).

\section{Factors determining multiple and informal borrowing}

Literature reveals that micro-credit clients in rural areas of Andhra Pradesh in India that belong to a backward class, and exclusively owns non-income generating assets are more likely to hold in multiple borrowings. Households possessing Capital goods and having access to a formal savings scheme reduces likelihood of multiple borrowing (Gambhir, 2012). Number of loan contracts of micro credit clients in Tanzania were significantly influenced by the Education level and number of dependants of the respondent (Mpogole et al., 2015). Ibekwe and Akpan (2016) identified Borrower's nonfarm income, credit amount received household size, net farm profit and farm size as significant determinants of informal credit delinquencies among food crop farmers in Nigeria.

\section{Farm Investment support schemes}

Governments across globe have been taking "reactive" policies like debt rescheduling, loan waiver and "proactive" policies like subsidized credit and farm investment support to release farm households from debt trap (Yastrebova, 2005). Numerous studies in India showed there was a minimal and insignificant effect of reactive policies on indebtedness of farm households (Chakraborty and Gupta, 2017; Raj and Prabhu, 2018). Hence, Proactive policies are becoming popular in the developing countries to address the issue of over-indebtedness. Agricultural investment support schemes are common in sub-saharan Africa and recently countries like India is also venturing into agricultural investment support through direct cash transfers (Cariappa and Srinivas, 2019). Most of the studies using advance econometric methods evaluated impact of cash transfers on food security, health, nutrition, education, livelihood and investment in productive assets (Asfaw et al., 2012; Prifti et al., 2019) and on crop production and productivity (Lubica Bartova, 2016; Ambler et al., 2017) but few studies were conducted on effect of farm investment support on households debt trap.

In this context this study was conducted with an objective to measure the effect of farm investment scheme on multiple and informal borrowing of the farm households with a hypothesis that there is a significant effect of investment support on reduction of multiple and informal borrowing.

\section{Materials and Methods:}

\section{Study area}

According to India's National Sample Survey Organization (NSSO) reports on situation analysis of farm household, Telangana state's 
rural Indebtedness among cultivators was second highest in the country with 89 percent of the households were indebted and majority of them are small and marginal farmers (See figure 1). Most of them rely on informal sources for borrowing and only 34.5 percent of the total outstanding amount was borrowed from the institutional sources (NSSO, 2013) (Directorate of Economics and Statistics, 2017). To release farm households from debt trap, Telangana state government has taken different proactive and reactive policies. One such prestigious proactive policy is "Rythubandhu".

\section{Rythubandhu" - An Agricultural Investment} support scheme in Telangana state, India:

The Telangana state government in India has launched an Agricultural investment support scheme "Rythubandhu" in the year 2018-19 to release farmers from debt trap. Under this scheme, A grant of $133^{1}$ USD is given per hectare per farmer each season (later increase to $\$ 167)$ to meet the material, labour costs and other investments of fields operations of farmer's choice for the crop season (GO Rythubandhu.Pdf, 2018). A budget of \$ 1.6 billion was sanctioned to this scheme in the financial year 2018-19. The scheme is still ongoing with a budget outlay of $\$ 1.8$ billion in the financial year 2020-21 reaching more than five million farmers in the state.

\section{Data collection}

Because of travel restrictions announced by the Indian government to curtail COVID 19 spread, the data from farm households was collected with help of undergraduate students who are staying at homes in rural areas of Telangana during COVID 19 lockdown period. Students who have completed Agricultural Finance course and trained in conducting farm holding survey were chosen for collecting data from farm households.
Google form was circulated among students to collect data. Data was gathered in the month of August, 2020 and in total 72 responses were collected from farm households by the students across different districts in Telanagna. Fig. 2 indicates number of responses collected from different districts in the state. Our data contain demographic, social and farm characteristics along with detailed information on household borrowing, expenditure, savings and investment support from the government for the financial year $2019-20^{2}$.

\section{Methods}

To meet objective of the study, a methodological approach is used in to find the effect of investment support on multiple and informal borrowing of the household. In the first part, extent of multiple borrowing and informal borrowing at farm household level is estimated. In second part, the effect of investment support on multiple and informal borrowing is estimated. Regarding indicators of multiple borrowing the practice of borrowing from different sources simultaneously is considered as multiple borrowing (Chichaibelu and Waibel, 2017). The most sophisticated definitions were proposed by Wampfler et al., 2014 i.e., when a household obtain multiple loans from single or several institutional or non institutional sources simultaneously is considered as multiple borrowing. A farm household may take loans for different purposes such as investment loans, crop loans, consumption loans and education loans etc. considering all these aspects a household is recognized as a multiple borrower if the household has multiple active loans outstanding simultaneously. A household is categorized as informal borrower If the credit is taken from informal sources like relatives, friends, neighborhoods, local merchants and local shops. 


\section{Econometric analysis}

Regression analysis is utilized to model and estimate determinants influencing multiple borrowing. Count data model is the most appropriate method as the dependent variable is a non-negative count,. The basic assumption to handle count data is that $\mathrm{Y}$ follows a poisson distribution, with probability density function.

$\operatorname{Pr}(Y=y / x)=\frac{\mathrm{e}^{-\mu} \mu^{y}}{y !}$, with $y=0,1, \ldots, m ;$ and $i=1, \ldots, n$

and

$\operatorname{Var}\left(\frac{y}{x}\right)=E\left[\frac{y}{x}\right]=\mu=e^{x \beta}$

With $\mu=$ expected mean $=$ variance $=(\mathrm{y} / \mathrm{x})$, where $\mathrm{y}$ is the count data variable, $\mathrm{x}$ are vectors of independent variable and $\beta$ are parameter to estimate (Jordán and Speelman, 2020).

\section{Quasi-Poisson regression}

Since Poission regression models assumes equi-dispersion of count data, it cannot be used under conditions of over and under dispersion. To test the null hypothesis of equidispersion in Poisson GLMs against the alternatives of under and over-dispersion that the variance is of the form.

$\operatorname{Var}(Y)=m u+\alpha * \operatorname{trafo}(m u)$

Over-dispersion corresponds to positive ${ }^{\alpha}$ and under-dispersion to negative ${ }^{\alpha}$. If underdispersion exists and ignored, parameter estimates of standard poisson regression will be consistent but standard errors of these estimates are biased upwards and variables appears to be not significant though significant (Cameron and Trivedi, 1986) (Wilson et al., 2018). Therefore, to overcome this problem, a quasi-poisson regression model (QP) can be used instead (Harris et al., 2012) (ERKAN et al., 2017) and (Wilson et al., 2018). In QP model, the dependent variable $\mathrm{Y}$ distribution is denoted as $\mathrm{Y}_{\mathrm{i}}=$ Poisson $\left(\vartheta_{i} \theta\right)$ with $\mathrm{E}\left(\mathrm{Y}_{i}\right)=\vartheta_{i}$ and $\operatorname{Var}\left(\mathrm{Y}_{i}\right)=$ $\theta \vartheta_{i}$, where $\theta$ is assumed to be unknown. This generalization implies aquasi-likelihood (Wedderburn, 1974). Hence, we assume for this QP model that $Y_{i} \sim$ QP $\left(\vartheta_{i}, \theta\right)$. Statistical software package $\mathrm{R}$ has dispersion options available that calculate the dispersion parameter, ${ }^{\alpha}$ and automatically adjust the biased errors and effects-test statistics (See table 1 for statistics on dependent and independent variables).

\section{Logit model}

Logit models were used to determine factors affecting informal borrowing among farm households in the study area. While the logit model is expressed as:

$\mathrm{Y}_{1}=\operatorname{Ln}\left(\mathrm{P}_{i} / 1-\mathrm{P}_{i}\right)=\alpha_{0}+\alpha_{1} \mathrm{X}_{1}+\alpha_{2} \mathrm{X}_{2}+\ldots .+$ $\alpha_{\mathrm{k}} X_{\mathrm{k}}+\mathrm{e}_{1}$

$\mathrm{Y}_{1}$ indicates dichotomous dependent variable which takes value one if farmer borrows from informal source and zero if doesn't. Statistics of dependent and independent variable are given in table 1. Hosmer-lemeshow goodness fit test is used to ensure the accuracy of the estimated probabilities (Nattino et al., 2020).

\section{Results and Discussion}

\section{Multiple and informal borrowing of Households}

The frequency of households by number of borrowings per annum is shown in Fig. 3. We found that 18 per cent of households had multiple borrowing ranging from two to four. Having at least one borrowing is common among households (46\%). Though NSSO 
reports that 89 per cent of Telangana rural households were indebted (NSSO, 2013), but only 64 per cent of sample households were indebted and 36 per cent of households doesn't have any debt to repay. Majority of the farmers borrows from institutions (85\%), only 15 per cent of the sample farmers borrows from informal sources like friends, relatives and input shop dealers. The purpose of informal borrowing is mostly to purchase inputs for crop production and to repay the old debt.

\section{Factors Affecting Multiple Borrowing}

Based on the dispersion test mentioned above, $\alpha=-0.466<0$ observed which represents the under-dispersion problem. When quasiPoisson model proceeds, Table 2 exhibits that capital assets possession and average monthly expenditure on consumption of livestock products like meat and milk have significant positive impact on multiple borrowing at $99 \%$ significance level. Whenever households acquires a capital assets like farm machinery or implements, number of loans taken by household increases by 20 percent.

However, household's possession of non income generating consumable assets has significant negative effect on multiple borrowing at $99 \%$ significance level. When a household's consumable asset position increases by one unit, number of loans taken by them decreases by 28 percent. These results contradicts with the past studies (Gambhir, 2012).

Operational landholding of household has significant positive effect on multiple borrowing at $95 \%$ level of significance. The number of borrowings increases by $18 \%$ if operation landholding of a farm household increases by one acre. Whereas, If area under irrigation increases by one acre the number of borrowings significantly decreases by 15 percent at 95 percent level of significance. If a household belongs to a scheduled tribes or castes community then the multiple borrowing decreases by 28 percent. Though the objective of investment support scheme is to reduce the debt burden on household but the benefit received under Rythubandhu doesn't have any significant effect on multiple borrowing.

\section{Determinants of informal borrowing by households}

Table 3 depicts determinants of household's informal borrowing. The Hosmer-Lemeshow test rejects the null hypothesis which indicates accuracy of the estimates. Educated farmers are 4 percent more likely to have an informal borrowing at 90 percent level of significance.

The likelihood of having informal loan increases by 3 percent if household's operational land holding increases. Capital asset position of a household increases the likelihood of informal borrowing by 7 percent where as consumable asset position decreases it by 7 percent at 95 percent level of significance.

Though total benefit received under Rythubandhu is significant at 90 percent but its average marginal effect is negligible on the likelihood of informal borrowing. Similarly, average monthly consumption expenditure on livestock products and annual agricultural income has negligible marginal effects on likelihood of informal borrowing.

\section{Note:}

1. Exchange rate $\$ 1$ (USD) = Indian Rupees 75/-

2. Financial year in India starts on $1^{\text {st }}$ April and ends on $31^{\text {st }}$ March. 
Table.1 The descriptive statistics for numerical variables

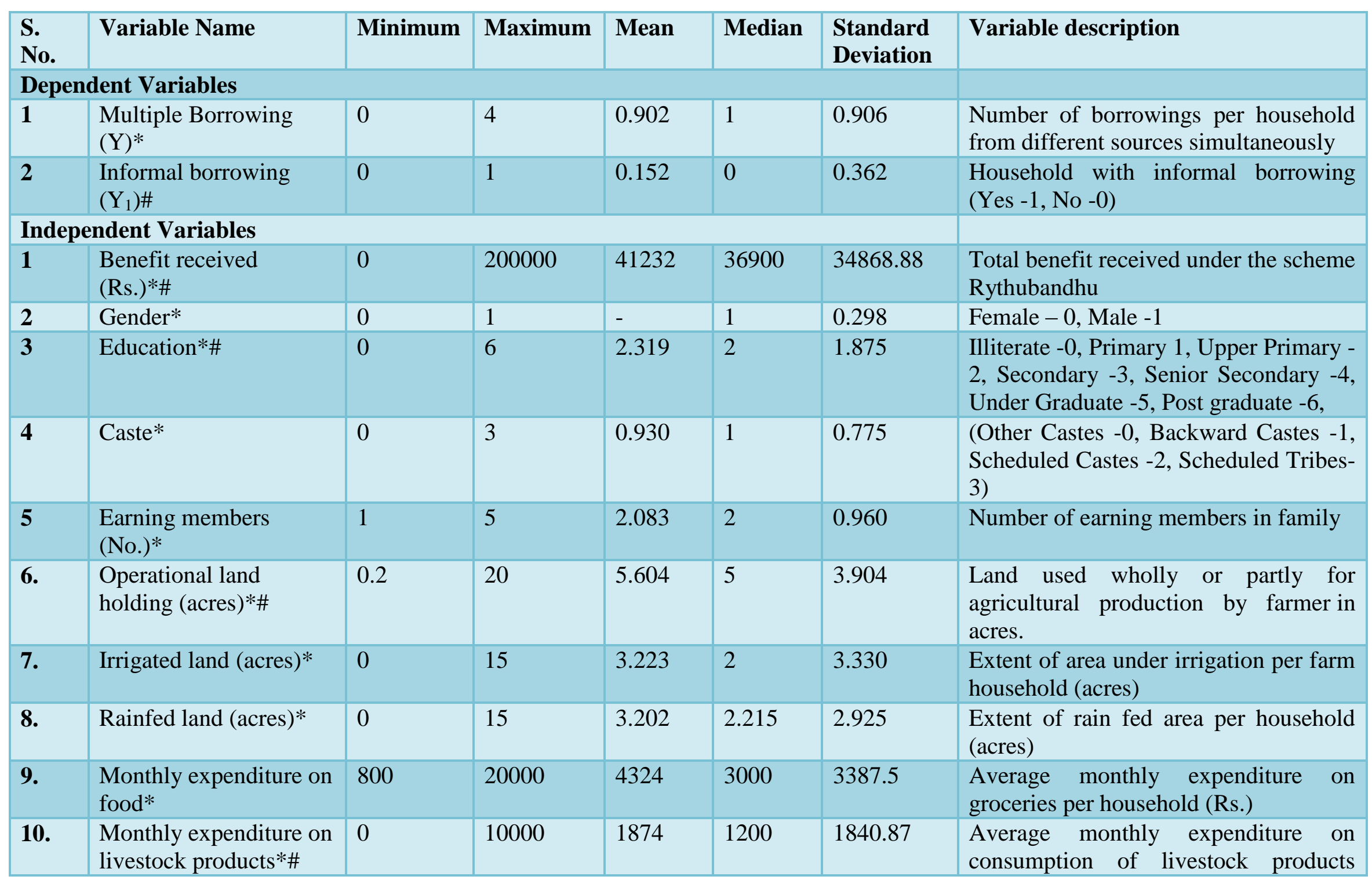


Int.J.Curr.Microbiol.App.Sci (2020) 9(12): 2555-2566

\begin{tabular}{|c|c|c|c|c|c|c|c|}
\hline & & & & & & & (Milk and meat) (Rs.) \\
\hline 11. & $\begin{array}{l}\text { Expenditure } \\
\text { Electricity } * \#\end{array}$ & 0 & 2500 & 528 & 400 & 513.28 & $\begin{array}{l}\text { Average monthly expenditure on } \\
\text { electricity usage per household (Rs.) }\end{array}$ \\
\hline 12. & $\begin{array}{l}\text { Institutional Savings } \\
(\text { Yes- } 1 / \mathrm{No}-0)^{* \#}\end{array}$ & 0 & 1 & 0.458 & 0 & 0.501 & $\begin{array}{l}\text { Whether saved money in formal } \\
\text { financial institutions (Yes- } 1 \text { / No- } 0 \text { ) }\end{array}$ \\
\hline 13. & $\begin{array}{l}\text { Annual income from } \\
\text { agriculture (Rs.) *\# }\end{array}$ & 5000 & 800000 & 122792 & 55000 & 157254 & $\begin{array}{l}\text { Annual net income derived from } \\
\text { cultivation of crop by household (Rs.) }\end{array}$ \\
\hline 14. & $\begin{array}{l}\text { Annual income from } \\
\text { livestock (Rs.)*\# }\end{array}$ & 0 & 600000 & 31486 & 0 & 96217.32 & $\begin{array}{l}\text { Annual net income derived from } \\
\text { rearing livestock by a household (Rs.) }\end{array}$ \\
\hline 15. & $\begin{array}{l}\text { Annual non farm } \\
\text { income (Rs.)* }\end{array}$ & 0 & 500000 & 32056 & 0 & 89161.31 & $\begin{array}{l}\text { Annual non-farm income of a } \\
\text { household (Rs.) }\end{array}$ \\
\hline 16. & Capital assets*\# & 0 & 10 & 4 & 3 & 2.830 & $\begin{array}{l}\text { Number of capital assets' possessed by } \\
\text { household (No.) }\end{array}$ \\
\hline 17. & Consumable assets*\# & 0 & 8 & 5.389 & 6 & 2.280 & $\begin{array}{l}\text { Number of consumable assets" } \\
\text { possessed by household (No.) }\end{array}$ \\
\hline
\end{tabular}

* Variables used in Quasi-Poisson Regression Model

\# Variables used in Logit model

'Capital assets include - Farm house, Cattle shed, farm machinery, implements and dug/bore Well etc.,

"Consumable assets include - two/four wheeler, refrigerator, Television, Telephone and ceiling Fan etc. 
Table.2 Factors affecting multiple borrowing by Household

\begin{tabular}{|c|c|c|}
\hline \multirow[t]{2}{*}{ Regressors } & \multicolumn{2}{|c|}{ Quasi-Poisson model (N = 72) } \\
\hline & $\exp$ (Estimate) & Std. Error \\
\hline Intercept & 2.072. & 0.5373 \\
\hline Gender (Male - 1 / female -0) & 0.7114 & 0.3707 \\
\hline Education & 1.0739 & 0.0762 \\
\hline Caste & 0.7237 & 0.1923 \\
\hline Number of earning members in family & 0.824 & 0.1734 \\
\hline Operational land holding (Acres) & 1.1889* & 0.0659 \\
\hline Irrigated land (Acres) & $0.8511 *$ & 0.0761 \\
\hline Rainfed land (Acres) & 0.9098 & 0.0604 \\
\hline Total benefit received under Rythubandhu (Rs.) & 1.0000 & 0.0000043 \\
\hline Monthly Expenditure on food & 1.0000 & 0.0000854 \\
\hline Monthly Expenditure on livestock products (Milk and meet) & $1.0002 * *$ & 0.0000854 \\
\hline Expenditure on Electricity & 0.9991* & 0.000362 \\
\hline Institutional Savings (Yes- 1 / No - 0) & 0.7656 & 0.2409 \\
\hline Annual income from agriculture (Rs.) & 0.9999* & 0.00000122 \\
\hline Annual income from livestock (Rs.) & 0.9999 & 0.00000219 \\
\hline Annual non farm income & 1.0000 & 0.00000173 \\
\hline Capital assets & $1.1987 * *$ & 0.0531 \\
\hline Consumable assets & $0.8282 * *$ & 0.06617 \\
\hline \multirow[t]{2}{*}{ Regressors } & \multicolumn{2}{|c|}{ Quasi-Poisson model (N = 72) } \\
\hline & $\exp$ (Estimate) & Std. Error \\
\hline Intercept & $2.072 .$. & 0.5373 \\
\hline Gender (Male - 1 / female -0) & 0.7114 & 0.3707 \\
\hline Education & 1.0739 & 0.0762 \\
\hline Caste & 0.7237 . & 0.1923 \\
\hline Number of earning members in family & 0.824 & 0.1734 \\
\hline Operational land holding (Acres) & $1.1889 *$ & 0.0659 \\
\hline Irrigated land (Acres) & 0.8511* & 0.0761 \\
\hline Rainfed land (Acres) & 0.9098 & 0.0604 \\
\hline Total benefit received under Rythubandhu (Rs.) & 1.0000 & 0.0000043 \\
\hline Monthly Expenditure on food & 1.0000 & 0.0000854 \\
\hline Monthly Expenditure on livestock products (Milk and meet) & $1.0002 * *$ & 0.0000854 \\
\hline Expenditure on Electricity & $0.9991 *$ & 0.000362 \\
\hline Institutional Savings (Yes- 1 / No - 0) & 0.7656 & 0.2409 \\
\hline Annual income from agriculture (Rs.) & $0.9999 *$ & 0.00000122 \\
\hline Annual income from livestock (Rs.) & 0.9999 & 0.00000219 \\
\hline Annual non farm income & 1.0000 & 0.00000173 \\
\hline Capital assets & $1.1987 * *$ & 0.0531 \\
\hline Consumable assets & $0.8282 * *$ & 0.06617 \\
\hline
\end{tabular}


Table.3 Factors effecting informal borrowing of a household

\begin{tabular}{|l|c|c|c|}
\hline \multicolumn{1}{|c|}{ Regressors } & Logit Regression (N = 72) & \\
\hline & $\begin{array}{c}\text { Exp } \\
\text { (Coefficients) }\end{array}$ & Std. Error & $\begin{array}{c}\text { Average } \\
\text { Marginal } \\
\text { effects }\end{array}$ \\
\hline Intercept & $\mathbf{0 . 0 7 2 5 5 .}$ & 1.497 & -0.1667. \\
\hline Education & 2.11974. & 0.4277 & $\mathbf{0 . 0 4 7 8 .}$ \\
\hline Operational land holding (Acres) & $\mathbf{1 . 6 0 0 8 2}$ & 0.2307 & $\mathbf{0 . 0 2 9 8}$ \\
\hline Total benefit received under & 1.00003. & 0.00002 & 0.0000021. \\
\hline Rythubandhu(Rs.) & & & \\
\hline $\begin{array}{l}\text { Monthly Expenditure on livestock products } \\
\text { (Milk and meat) }\end{array}$ & $\mathbf{1 . 0 0 1 8 * *}$ & 0.0007 & $0.000148^{* *}$ \\
\hline Expenditure on Electricity & $\mathbf{0 . 9 9 2 6 6 .}$ & 0.0038 & -0.000468. \\
\hline Institutional Savings (Yes- 1 / No - 0) & $\mathbf{0 . 0 7 9 2 3 .}$ & 1.4490 & $\mathbf{- 0 . 1 6 1 1 .}$ \\
\hline Annual income from agriculture (Rs.) & $\mathbf{0 . 9 9 9 9 7 * *}$ & 0.00001 & $-0.00000823^{* *}$ \\
\hline Annual income from livestock (Rs.) & 0.99984 & 0.0001 & -0.00000997 \\
\hline Capital assets & $\mathbf{3 . 1 4 6 8 6 *}$ & 0.4487 & $\mathbf{0 . 0 7 2 8 *}$ \\
\hline Consumable assets & $\mathbf{0 . 2 9 2 8 1 * *}$ & 0.4667 & $\mathbf{- 0 . 0 7 8 * *}$ \\
\hline Hosmer-Lemeshow test (p-value) & 0.5931 & & \\
\hline St & & & \\
\hline
\end{tabular}

Statistical Significance levels ‘**’ 0.01 ‘*’ 0.05 '.’ 0.1

Fig.1 Share of indebtedness in different states in India

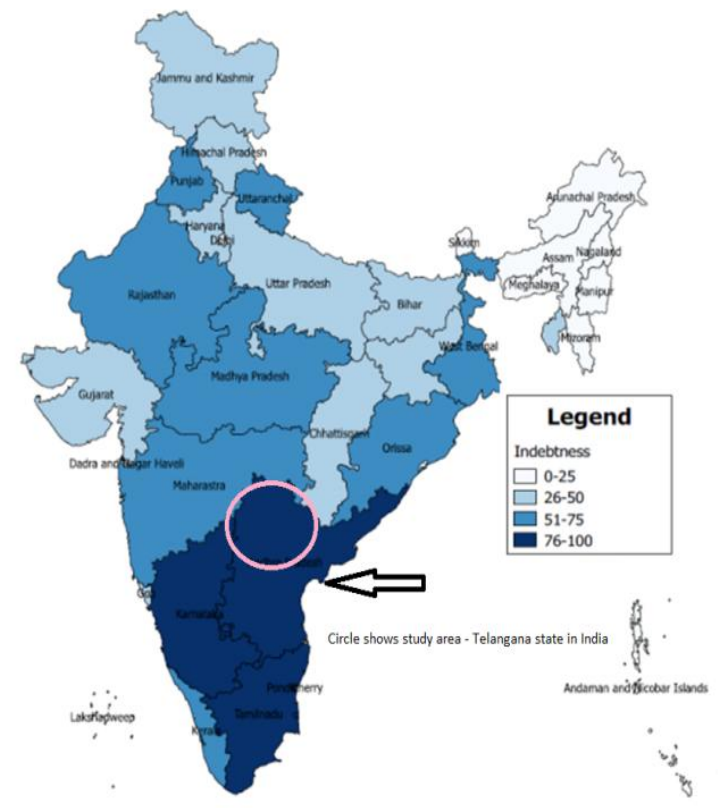

Source: (Subash Surendran Padmaja and Jabir Ali, 2019) 
Fig.2 Number of responses collected from farm households across different districts of Telangana state, India

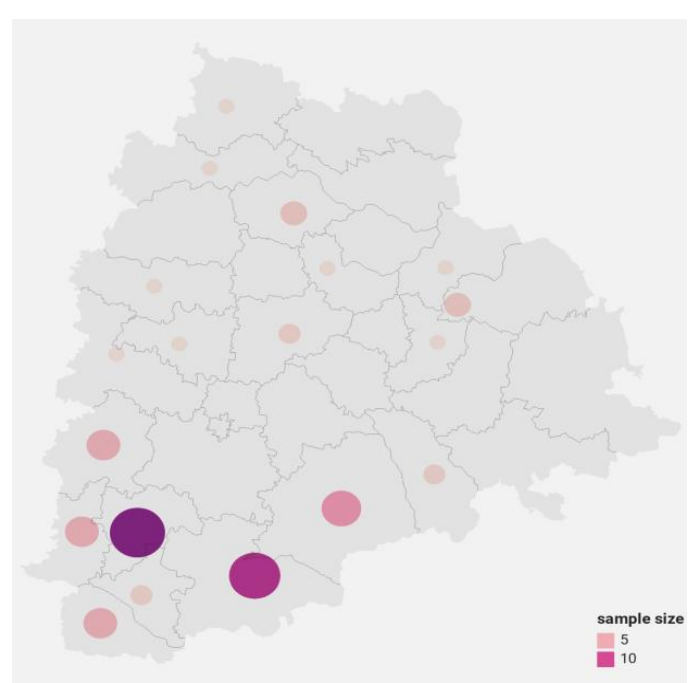

Fig.3 Multiple borrowing: Frequency of households by number of borrowings

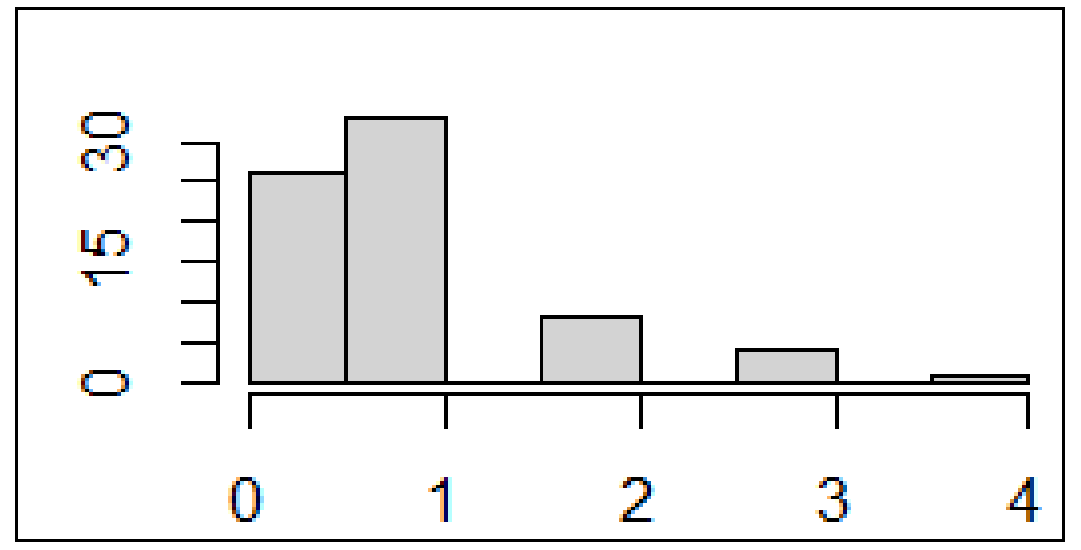

In conclusion, over-indebtedness is emerging as major problem across farm households of the developing economies. Several studies concluded that multiple and informal borrowing are the important factors contributing for household over-indebtedness. Proactive policies like Farm investment support schemes are becoming popular across developing economies to address this issue. Studies on effect of these schemes on overindebtedness are seldom. This study was conducted to study the effect of farm investment support scheme "Rythubandhu" implemented by Telangana government in
India on multiple and informal borrowings of the households. Results of study indicate that farm investment support may not necessarily reduce the multiple and informal borrowing of a farm household but providing irrigation has significant effect on reducing overindebtedness.

\section{Acknowledgment}

We are grateful to the undergraduate students who helped in data collection during the COVID-19 pandemic and also farmers participated in household survey. 


\section{References}

Bhattacharjee, M., and Rajeev, M. (2013). Modeling loan repayment behavior in developing countries. Applied Economic Perspectives and Policy, $35(2)$, 270-295. https://doi.org/10.1093/aepp/ppt009

Cariappa, A. G. A., and Srinivas, A. (2019). Universal Basic Income for India: The Way Towards Right to Equality-A Review. Indian Journal of Economics and Development, 15(1), 142. https://doi.org/10.5958/23220430.2019.00016.7

Chichaibelu, B. B., and Waibel, H. (2017). Borrowing from "Pui" to Pay "Pom": Multiple Borrowing and OverIndebtedness in Rural Thailand. World Development, 98, 338-350. https://doi.org/10.1016/j.worlddev.201 7.04 .032

Chichaibelu, B. B., and Waibel, H. (2018). Over-indebtedness and its persistence in rural households in Thailand and Vietnam. Journal of Asian Economics, 56 , $1-23$. https://doi.org/10.1016/j.asieco.2018.0 4.002 .

Directorate of Economics and Statistics. (2017). Pocket Book of Agricultural Statistics.

http://agricoop.nic.in/sites/default/files /pocketbook_0.pdf

ERKAN, G., EVKAYA, O., and TÜRKAN, S. (2017). Determination of the Affecting Factors of the Number of Babies Born Alive in Multiple Pregnancies with Poisson Models. Turkiye Klinikleri Journal of Biostatistics, 9(3), 222-229. https://doi.org/10.5336/biostatic.201757306

Gambhir, R. (2012). Determinants of multiple borrowing among micro-credit clients in rural Andhra Pradesh.
GO Rythubandhu.pdf, Pub. L. No. G.O.Rt.No.231， 1 (2018). http://rythubandhu.telangana.gov.in/D efault_RB1.aspx (accesses on July 3, 2020)

Harris, T., Yang, Z., and Hardin, J. W. (2012). Modeling underdispersed count data with generalized Poisson regression. In The Stata Journal (Vol. 12, Issue 4).

Jordán, C., and Speelman, S. (2020). On-farm adoption of irrigation technologies in two irrigated valleys in Central Chile: The effect of relative abundance of water resources. Agricultural Water Management, 236(March), 106147. https://doi.org/10.1016/j.agwat.2020.1 06147

Klühs, T., Koch Wiebke Stein, M., Schmidt, K. M., Koch, M., Stein, W., thank Anik Ashraf, W., Friedrichsen, J., Grohmann, A., Klonner, S., Lenel, F., Menkho, L., Spantig, L., Steiner, S., Soubeiga, S., Stöckl, F., Thomsen, S., and Wagener, A. (2018). Don't Expect Too Much-High Income Expectations and Over-Indebtedness. www.rationality-and-competition.de

Liu, E., Roth, B. N., Acemoglu, D., Ashlagi, I., Banerjee, A., Bhattacharya, V., Olken, B., Kominers, S., Kuebler, D., Lo, S., Myerson, R., Niederle, M., Pei, H., Prendergast, C., Straub, L., Townsend, R., and Weizsäcker, G. (2016). Keeping the Little Guy Down: A Debt Trap for Informal Lending. http://economics.mit.edu/grad/benroth ]

Lubica Bartova, J. H. (2016). Estimation of farm investment support effects: A Counterfactual approach. In S. Vrátna (Ed.), Quantitative methods in economics Multiple Criteria Decision Making XVIII (pp. 19-24). Letra Interactive, s. r. o.

Mpogole, B. H., Mwaungulu, I., and Mlasu, 
S. (2015). Multiple Borrowing and Loan Repayment: A Study of Microfinance Clients at Iringa, Multiple Borrowing and Loan Repayment: A Study of Microfinance Clients at Iringa, Tanzania MultipleBorrowingandLoanRepaymen tAStudyofMicrofinanceClientsatIringa

, Tanzani. Global Journal of Management and Business Research, 12(August).

Nattino, G., Pennell, M. L., and Lemeshow, S. (2020). Assessing the Goodness of Fit of Logistic Regression Models in Large Samples: A Modification of the Hosmer-Lemeshow Test. https://doi.org/10.1111/biom.13249

NSSO. (2013). Income, Expenditure , Productive Assets and Indebtedness of Agricultural Households in India. Report No. 576 (70/33/3). http://mospi.nic.in/sites/default/files/p ublication_reports/nss_rep_576.pdf

Pandey, B., Bandyopadhyay, P., and Guiette, A. (2019). Impact of different sources of credit in creating extreme farmer distress in India. Benchmarking. https://doi.org/10.1108/BIJ-10-20180321

Puliyakot, S., and Pradhan, H. K. (2018). Over-Indebtedness Among Microfinance Borrowers: A Poverty Line Based Approach. SSRN Electronic Journal, 1-18. https://doi.org/10.2139/ssrn.3088917

Subash Surendran Padmaja, J. A. (2019).
Correlates of Agrarian Indebtedness in Rural India Downloaded. Journal of Agribusiness in Developing and Emerging Economies, 8(2), 1-40. https://doi.org/10.1108/JADEE-042017-0048

Thorat, V. S. (2020). Incidence and Determinants of Indebtedness of Agricultural Households in Gujarat. Economic Affairs, 65(2), 249-254. https://doi.org/10.46852/04242513.2.2020.17

Wilson, S. R., Leonard, R. D., Edwards, D. J., Swieringa, K. A., Wilson, S. R., Leonard, R. D., Edwards, D. J., and Kurt, A. (2018). Inference for underdispersed data: Assessing the performance of an airborne spacing algorithm. Quality Engineering, 30(4), 546-555.

https://doi.org/10.1080/08982112.201 8.1482339

World Bank. (2020). World Bank. 2020. Global Economic Prospects, June 2020. Washington, DC: World Bank. (C) World Bank. https://openknowledge.worldbank.org/ handle/10986/33748 License: CC BY 3.0 IGO. (Issue June).

Yastrebova, O. (2005). Non payments, Bankruptcy and Government Support in Russian Agriculture. Comparative Economic Studies, 47(1), 167-180. https://doi.org/10.1057/palgrave.ces. 8 100088.

\section{How to cite this article:}

Sravanthi Kolla and Raghu Rami Reddy, P. 2020. Effect of Farm Investment Support on Multiple and Informal Borrowing of Farm Households: A Case Study on Rythubandhu Scheme in Telangana, India. Int.J.Curr.Microbiol.App.Sci. 9(12): 2555-2566.

doi: https://doi.org/10.20546/ijcmas.2020.912.304 